\title{
A Freudian Reading of Samuel Richardson's Pamela
}

\author{
Shadi Torabi Sarijaloo \\ Department of English Literature, Karaj Branch, Islamic Azad University, Alborz, Iran \\ E-mail: Shadi.torabi89@gmail.com \\ Shahram Kiaei (Corresponding author) \\ Faculty Member, Qom Branch, Islamic Azad University, Qom, Iran \\ E-mail: shahramkiaei@yahoo.com
}

Received: 02-09-2015

Published: 01-03-2016
Accepted: $30-11-2015$

doi:10.7575/aiac.ijalel.v.5n.2p.30
Advance Access Published: December 2015

URL: http://dx.doi.org/10.7575/aiac.ijalel.v.5n.2p.30

\begin{abstract}
Richardson's Pamela (1740_1) is replete with elements and incidents that make it worthy enough to be viewed from Freud's perspective. The present study focuses upon how Richardson's characters unconsciously attempt to conceal and repress their own conflicting emotions, thoughts, wishes, impulses and how they struggle against their anxiety-ridden situations to regain their psychic balance. Moreover, the repetition of certain occurrences and elements play a crucial role in generating the uncanny effect in Pamela, including the role of double and déjà-vu, the castle-like settings, heroine's intimidating situations and also her master's past secret. In addition, the way Richardson's characters dress for the noteworthy masquerade ball scene and the ambiguous words of Pamela's master are considerably implies something that is affiliated with characters' psyche according to Freud's condensation theory. With regard to Freud's concepts of The 'Tripartite Psyche', 'Anxiety and Ego Defense Mechanisms' and 'Uncanny' the researcher attempts to delve into the heroine and her master's psyche through her letters which reveal the contents of the heroine's unconscious mind.
\end{abstract}

Keywords: Tripartite Psyche, Anxiety and Ego Defense Mechanisms, Uncanny

\section{Introduction}

The present study applies Freudian psychoanalysis to Richardson's Pamela (1740-1). Samuel Richardson (1689-1761) is one of the most celebrated novelists of the eighteenth century since he introduced a new kind of novel writing which is called epistolary novel. His major works are Pamela (1740-1), Clarissa (1747-8) and Sir Charles Grandison (17534). Pamela was thrilling among readers on its first publication; also it was the best-selling novel of its time and it was translated into French (Keymer 31-2). Indeed, Pamela consists of two intimately related novels. The first two volumes, Pamela: or, Virtue Rewarded (1740), were depicting a young maidservant girl's apprehension before her marriage in the stratified society of the eighteenth-century England and the following two volumes, Pamela in Her Exalted Condition (1741), were dealt with the heroine's perturbation in her genteel life after she climbed up the social ladder owing to her marriage to her high-born lord.

Although Richardson dedicated only fourteen years of his life for writing his influential novels, he remained active in the printing industry for his whole adult life. Actually, he was a successful printer and he commenced novel writing very late in his life. In addition, he acquired knowledge about the contemporary issues through printing the debates of parliament for the House of Commons (Doody 98). Keymer and Sabor argue that his novels' epistolary form provides the readers' access to the ebb and flow of consciousness which is not hindered by the effects of retrospection. Later Richardson himself called this technique "writing to the moment". As they clarify two related traits, this technique captures to perfection "not just its capacity to register the flux of consciousness over time, but more particularly its dramatic synchronizations of narration and crisis, with focus above all on the immediate psychological impact of 'moments' in the sense of turning-points or critical junctures" (21).

\subsection{Statement of the Problem}

Psychoanalytic concepts have long been an integral part of our lives. We appreciate the significance of these concepts since our lives are strongly influenced by them and we are able to comprehend that human conduct which arouses a feeling of puzzlement within us by understanding, apprehending and applying these key concepts. Thus, we can deeply grasp the implications of those literary texts that are associated with human behavior through application of psychoanalytic concepts (Tyson 11). Freud's contributions to psychology are very vast and he presented many theories that touch something profound in the human psyche and we can analyze the reasons of our various behaviors.

Richardson represented Pamela's character like an angel in the fairy tale who brings about moral reformation in her high-born libidinous lord by her stubborn resistance and exaggerated goodness. Indeed, he portrayed his heroine as a wellspring of virtue and piety who can be a perfect moral pattern in order to propagate moral principles among the youth of the eighteenth-century England's society, but the inner motivations of Richardson's characters for their conduct 
are more complicated and the hero's moral conversion as well as the heroine's highly exaggerated forgiveness cannot be as simple as the author depicted them throughout the novel. Richardson's works have been investigated through different points of view, including cultural, linguistic, gender matters, psychological, feminist and Marxist, but this research is mostly concerned with psychological reading respecting Freud's notions of the 'Tripartite Psyche', 'Anxiety and Ego Defense Mechanisms' and 'Uncanny' in Richardson's Pamela.

With regard to the above Freud's notions, the researcher examines heroine's letters in order to reach the depth of her psyche and reveal the content of her unconscious, including her hidden and conflicting emotions, fears, desires and anxieties. Moreover, the researcher proceeds to explore the conduct of Pamela's opposite role, her master, based on Pamela's description in her letters. In order to prove that how the problem is confirmed, there are some questions to be answered in this thesis:

1. According to Freud's concept of 'Anxiety and Ego Defense Mechanisms', what do the main characters' interior and exterior motivations demonstrate in Pamela?

2. How can Freud's notion of 'The uncanny' be traced in Pamela?

3. What are the influential elements in molding the heroin's hyperactive superego in the above-mentioned novel?

\section{Methodology}

The twentieth century's turmoil is affiliated with the human personality and human relationships as well as economic and social causes, but the feelings and experiences such as anxiety, self-fragmentation and fear of harassment are crucial in founding new systematic field of knowledge which is called psychoanalysis by Sigmund Freud in the late nineteenth century (Eagleton 131). His contributions to psychoanalysis are very vast and one of his radical theories which still has a key role in classical psychoanalysis is the concept of unconscious. Gardner clarifies that Freud differentiates between descriptive and dynamic sense of the unconscious and he argues that psychoanalysis deals with its dynamic sense. Indeed, the dynamic sense of unconscious considers a source of motivation which brings about mental conflict. This hypothesis conceived with regard to "the clinical phenomena of resistance and transference" that they manifest themselves through our dreams and failure in our memories vaguely (137).

Lapsley and Stey discuss that our psyche is divided into conscious and unconscious which forms topographical model. Unconscious is the storehouse of our repressed and forbidden ideas and desires which eventually leads to psychic conflict and they are struggling against the repressive forces of conscious ego. The contents of our unconscious are illogical and timeless; also they try to find a way to discharge themselves (4).

In 1923 Freud represented one of his most prominent models of the human psyche which was named the tripartite model. With regard to this model, the human psyche is divided into three distinct parts and each part makes an attempt to accomplish its own objective according to different principles (Booker 29). Nye expresses that the id is regarded as a kind of fundamental system which we are equipped with it during our childhood. The id's aim is to satisfy its own instinctual desires without respect to any limitation, restraint and prohibition (22). The ego as the executive of the personality tries to apply its available psychic energy to prevent the id from gratifying its own irrational desires. The rational ego attempts to attain its own objective based on the reality principle and it is deemed to be both a servant and master of the id at the same time. Its mastery gets back to its power to delay gratification until reality is served.

Furthermore, the judicial part of our personality is called superego. It functions as a moral mediator and it is the manifestation of the ideal. It tries to accomplish perfection rather than pleasure. In Freud's view, all children gradually begin to internalize the ethical standards of their parents between the ages of three to six. Therefore, the child's superego is formed by these international codes of conduct (C. Gines et al. 21).

Nye maintains that anxiety acts as an alerting agent that forewarns ego about the danger. Anxiety will intensify, in case the ego becomes weak, but on the other hand ego will adapt itself to various situations if it is benefited from its defenses. Freud suggests three kinds of anxiety, including reality, neurotic and moral anxiety (42). Likewise, we feel anxiety when ego defense mechanisms fail to work properly. Anxiety is of crucial importance since it represents our core issues like fear of intimacy, fear of abandonment, fear of betrayal and low self-esteem (Tyson 16).

To protect ourselves from anxiety, we unconsciously use ego defense mechanisms. The application of these defenses is expressive of an ego that was weakened by its surrounding situations. These defenses distort reality and they operate unconsciously, in addition, the most common of them, including repression, denial, projection and displacement (43). Freud considers five significant features for ego defense mechanisms. Firstly, they function as a major means of controlling instincts and impulses and secondly, they operate unconsciously. Their third property is that they are discrete from one another; also their forth trait is related to their dynamic and reversible nature and finally "they can be adaptive as well as pathological" (Vaillant 4).

The concept of the uncanny was suggested by the psychiatrist Ernst Jentsch for the first time. He claims that the uncanny is a product of "intellectual uncertainty", therefore, the uncanny is concerned with something which is unfamiliar to us. "The better oriented in his environment a person is, the less readily will he get the impression of something uncanny in regard to the objects and events in it" (qtd. in Freud 931). Later Freud elaborated on this concept. He defined it as the strange in the familiar and the familiar in the strange; also the experience of uncanniness is related to our unconscious desires and beliefs that are repressed and they attempt to reach the surface of consciousness. Actually, the uncanny is considered as the return of the repressed since the reappearance of the repressed arouses a feeling of fear. 
Freud regarded dreams as the royal road to the unconscious realm. During our dream, the unconscious attempts to distort and soften its desires, therefore, our dreams are deemed to be a symbolic text which should be deciphered. While we are dreaming, the watchful ego is still active and it tries to censor and convert an image into something indistinct (Eagleton 136). In essence, Freud hypothesized that when we sleep, our abstract thoughts convert into visual images and dramatic narratives. Furthermore, Freud introduced a new term for the mind's dream making process; he named it the "dreamwork" which includes condensation (Packer 35). In this process, one element of a dream signifies numerous things in waking life like when a family dog symbolizes the whole family (Hergenhahn 562).

\section{Discussion}

\subsection{Character's Anxieties and Their Defense Mechanisms in Pamela}

Nye elucidates that an individual unconsciously applies his ego defense mechanisms such as repression, denial, displacement and projection when the ego becomes weak. This situation may become temporary and negligible or it may be serious and take long time (43). Tyson clarifies that one experiences anxiety when he cannot apply his defenses properly. Thus anxiety is considered as an important involvement because it reveals our core issues, including fear of intimacy, fear of abandonment and low self-esteem (16). Freud refers to three kinds of anxieties, including Reality Anxiety, Neurotic Anxiety and Moral Anxiety (Nye 42). To my estimate, this novel is the embodiment of the anxious situations which Pamela and her master, Mr. B., are trying to challenge with them by using their ego defense mechanisms unconsciously.

\subsubsection{Core issues and Defenses in Squire B.'s Persona}

As we can see throughout the novel, Squire B suffers from the fear of abandonment which causes him to endure fear of intimacy. His insistence to persuade Pamela to become his mistress is rooted in his past painful experiences such as his failed affair with Sally Godfrey, the loss of his mother, and also his past way of life. He unconsciously believes that he can remain emotionally safe if he keeps himself away from any emotional ties to another human being. At the first page of the novel we notice the death of Lady B, and after the death of his mother, he is attracted to his mother's highly favored maid, but Mr. B as a dissipated high-class man has no intention for marriage due in part to his reality anxiety of being abandoned by the gentry and his own family he prefers to keep Pamela in his state as his mistress in order to gratify his instincts and then goes to experience another relationship.

Abjadian explains that Pamela has a complicated social class background and the marriage between a poor maid servant and her noble-born master is not as simple as Richardson depicted it throughout the novel because the eighteenthcentury England was infatuated with the social position and it admired the gentry and envied them (458). Mr. B. is completely aware of this fact and he does not intend to sacrifice his social position for a lowborn girl like Pamela and become a social outcast by the gentry and his own family. Therefore, when he notices that he becomes fascinated by a lowborn girl he tries to project his feelings on parson Williams and in his letter to the heroine's father, he claims that Pamela has a long distance affair with a young priest and he decided to send her into his country state for a while in order to prevent any dishonor.

To make this explicit, Shariat Kashani clarifies that the Projection is a kind of defensive reaction towards an individual's fears, tensions, and internal conflicts. In this process, one attempts to ascribe all his unpleasant conduct and feelings as well as his vague impulses to another person (98). As Mr. B. ascribes his unacceptable feeling to parson Williams in his letter to Mr. Andrews, "I believe her very honest, and very virtuous; but I have found out also, that she is carrying on a sort of Correspondence, or Love Affair, with a young Clergyman, that I hope in time to provide for; but who, at present, is destitute of any Subsistence but my Favour... And for this reason I have sent her out of his Way for a little while" (Pamela 60).

As we can see in this novel, pursuing a maidservant and having an affair with her conspicuously are not deserving of a gentleman's behavior in that hierarchical society of the eighteenth-century England. For this reason, B. cannot recognize and accept his own feelings and he tries to project his feelings onto parson Williams. Moreover, when B has hidden himself in his maid's closet and tries his first sexual attack on her which remains unsuccessful due to her swoon and after Pamela insists to preserve her honor and virtue, B. becomes quarrelsome, as he addresses his rage to her, "I don't want such idle sluts to stay in my House" (Pamela 33). Thus, he ascribes all his deceitfulness and hypocrisy to her and he warns Mrs. Jervis, the Bedfordshire's housekeeper and later Mrs. Jewkes, the Lincolnshire housekeeper that she should be watched carefully due to her skill to deceit others. One of the possible explanation for his reaction might be his concern over losing his credit and honor through this servant girl's reports. As a result of this, he attempts to project his wrong conduct onto her and accuses her of being a pert and dishonest girl.

Eventually when B. realizes that Pamela will not consent to be his mistress, he asks her to let him read all her letters. Harris clarifies that the episode in which the heroine delivers up her text to her master is called textual rape. Although she is unwilling to deliver them up to him, it makes her become his legal wife (177). After his recurrent abortive efforts to rape Pamela physically and satisfy her to become his mistress, he decides to rape her textually and calms himself down by reading her letters and trying to know her inner part. Indeed, B. is unconsciously benefited by displacement and his desire to textually rape his servant displaces his desire to physically rape her.

Moreover, he has lost his mother recently and he is overwhelmed by the feeling of loss that leads to his fear of abandonment. He unconsciously believes that if he keeps himself away from any emotional ties, he can remain in the position of power and he might never experience that psychological pain. Additionally, when Lady Davers, B's sister wrangles with Pamela in order to know whether she is legally married to her master or not, she tells Pamela that "But 
when, as I fear, you have suffer'd yourself to be prevail'd upon, and have lost your Innocence, and added another to the Number of the Fools he has ruin'd, (This shock'd me a little!) I cannot help shewing my Displeasure to you" (Pamela 230). Thus it is obvious that B. has multiple relationships and Pamela is not the first case for him who tries to achieve his own wish and then goes to have another liaison. Indeed, the eighteenth-century England's social codes were tolerant towards high-class men's dissipation and as a member of the gentry, Mr. B.'s attempt not to involve himself deeply in none of his relationships, is indicative of his fear of intimacy as a kind of defense to remain in his position of power and to strive against his Reality Anxiety which he faces in other words.

Furthermore, B.'s failed affair with Sally Godfrey which eventually leads to the birth of his illegal daughter, Miss. Goodwin, is indicative of his Neurotic anxiety. He unconsciously fears that the impulses of his id rebel against him and causes him to involve in another trouble. He tries to absolve himself of all responsibility by accusing Sally's mother of deceitfulness. As he denies his blame and justifies himself in this way:

When I was at College, I was well received by a widow Lady, who had several Daughters, and but small Fortunes to give them; and the old Lady set one of them; a deserving good Girl she was; to draw me into a marriage with her, For the sake of Fortune I was Heir to; and contriv'd many Opportunities to bring us and leave us together. I was not then of Age; and the young Lady, not half so artful as her Mother, yielded to my Addresses, before the Mother's Plot could be ripen'd, and so utterly disappointed it. This, my Pamela, is the Sally Godfrey this malicious Woman, with the worst Intentions, has inform'd you of (Pamela 260).

However in this part, B. applies Freud's denial defense mechanism and he tries to justify his action unconsciously. He tries to indicate that he is blameless in Sally's case, but later we find out B. is not a reliable narrator because after Sally bears her childbed's suffering and gives her baby to B.'s sister in order to bring her up secretly, he was very sorrowful when Sally boarded the ship in order to depart him, as he describes his feelings, "and then I gaz'd at the Ship, till and after I had landed, as long as I could discern the least Appearance of it; for she was under Sail, in a manner when I left her: And so I return'd, highly disturb'd, to my Inn" (Pamela 292).

To this end, he is somehow defeated in his relationship with her and he represses his painful memories of her to his unconscious and he changes his mind about his decision on the sham-marriage for this reason in order to restrain himself from experiencing these painful memories again.

Likewise, his secret extramarital affair with the countess refers to his fear of intimacy. Indeed he unconsciously intends to keep himself safe from any emotional dependence and intimacy by dividing his time and interest between two women. Regarding this point, Dussinger states that "B.'s conversion, clearly, is not the simple modus operandi of romantic plots that Richardson condemned but an awareness earned under the duress of feelings controlled by art and memory, and of course Pamela II illustrates that there is no security from "relapse" when B has the affair with the countess" (388).

\subsubsection{Pamela's Internal Conflicts and Her Defenses}

Pamela's excessive forgiveness is rooted in her fear of intimacy and her low self-esteem. Tyson illustrates that a woman, who is infatuated with a man who suffers from intense fear of intimacy, has a fear of intimacy herself and she can intensely applaud him since there is no threat to "her protective shell" (41). As we see in the novel the heroine suffers from the fear of intimacy and she is completely aware that B has no desire for intimacy and his rakishness. As a consequence, by accepting his marriage proposal she knows that she is secure from any danger which could be a threat to her protective shell. Pamela's exaggerated forgiveness of B.'s past and present misconduct is indicative of her low self-esteem which is rooted in her religious beliefs of her parents that have important role in shaping her superego, thus she unconsciously believes that she does not merit better.

Nye clarifies that Reality Anxiety happens when an element from real world is threatening a person. In this situation, an individual faces with realities and conditions which are dangerous. Anxiety can apply as a stimulus to eliminate danger and in a case that one cannot apply an appropriate reaction, anxiety increases and debilitates the person. Pamela faces with such a situation which constantly threatens her honor and moral values (42).

The heroine's situations, including B's recurrent sexual attacks, her imprisonment in Lincolnshire under the stern eye of the housekeeper, Mrs. Jewkes and her growing sexual attraction to her master lead her to hysteria. As Doody explains that there are some moments that the heroine loses her courage, as she attempts to escape from Lincolnshire, she is afraid of the sight of the bulls which are just two poor cows. Indeed, Richardson by depicting this scene, wanted to say that "the obstacle to Pamela's escape resides within herself" and it is only the protagonist's fancy that relates these two bulls with Mr. B. and Mrs. Jewkes. In other words, Richardson tried to throw light on her confusing situation, the depth of her psyche and also her internal conflicts (103-4). Her intensive reality anxieties end up in her hallucination and her visual error which prevent her from distinguishing and escaping.

The heroine's growing sexual attraction to her master is one of her internal conflicts which she tries to repress generally because her feelings and thoughts do not correspond to her moral values and her religious instructions of her parents which are molded her superego. Thus she feels ashamed of herself while she is thinking about them. As she describes her secret feelings and revealing her unconscious through her letter writing. This can be illustrated by Pamela's rejoicing over hearing about her master's safety after he was rescued from drowning when he went hunting. As she describes her own feelings, "To be sure, I am not like other People! I am sure he has done enough to make me hate him; but yet when I heard his Danger, which was very great, I could not in my Heart forbear rejoicing for his Safety; tho' his Death would have ended my afflictions" (110). 
Similarly, when she looks at her master through the window and admires his appearance, she reveals her unconscious and real feelings towards him which she attempts to repress them. As she mentions in her letter, "I look'd after him, out of the window, and he was charmingly dress'd: To be sure, he is a handsome fine Gentleman! What a pity his Heart is not as good as his Appearance! Why can't I hate him?" (120). Furthermore, when B. eventually consents to Pamela's departure from Lincolnshire, It is strange that she is not willing to leave there. As she writes about her feelings "I think I was loth to leave the House. Can you believe it? What could be the Matter with me, I wonder! I felt something so strange, and my Heart was so lumpish! I wonder what ail'd me!" (148).

As Margaret Ann Doody in her article which is entitled "Samuel Richardson: Fiction and Knowledge" states that the nineteenth-century literature consider Richardson's personages as characters since they include "inner depths and irrationalities". As Pamela consciously finds out her feelings and thoughts are in conflict with her moral values. She has an internal conflict because she tries to conceal her real feelings from herself. If she accepts them, she will be lost, "falling into degraded position that Mr. B wants her to assume, and injuring herself deeply" (104). Accordingly, she tries to repress all of her unacceptable feelings and throw them to her unconscious that eventually causes her to become hysteric, including her repeated fainting fits and her decision to commit suicide.

Pamela is also obsessed with the case of Sally Godfrey, she writes her thoughts down, "and I went up to my Closet, to ruminate on these things. And, foolish thing that I am, this poor Miss Sally Godfrey runs in my head!" (Pamela 263). Although her mind is obsessed with this unpleasant B's past secret, she attempts to repress her curiosity about this matter due to her hyperactive superego, "Not one Hint did he give, that I durst lay hold of, about poor Miss Sally Godfrey. I wish my lady had not spoken of it. For it has given me a curiosity that is not quite so pretty in me" (Pamela 272).

\subsubsection{Pamela's Letter writing as her Defense}

The heroine tries to repress all her unpleasant thoughts and feelings by writing. As soon as she is exposed to an anxietyridden situation she seeks refuge in her closet room and starts writing. In other words, she calms herself down through writing. J. W. Fisher, in his essay, "Closet Work: The Relationship Between Physical and Psychological Spaces in Pamela", has stated that Pamela's letters and journal display the reflection of her inner life and she reveals all her immediate thoughts, conflicting emotions and also her dramatic tension by the "method of writing to the moment". The physical settings of the scenes which are depicted in Pamela's letters have a psychological significance, for instance, when she is at Bedfordshire house, she is afraid of the closet room where her master attempted to sexually attack her, but her locked closet becomes her sanctuary when she becomes a prisoner at Lincolnshire house (22-3).

Furthermore, Fisher mentions every time that the heroine's psyche becomes disturbed, she resorts to her closet and begins to write her emotion down. "After her wedding and before the consummation devoutly to be wished, Pamela says, "I took refuge in my Closet, and had recourse to Pen and Ink, for my Amusement and to divert my Anxiety of mind"(II, 148)" (34). Additionally, in her letter which she writes to Miss Darnford, she states that she tries to calm herself down by resorting to her closet and divert herself from expecting to see her husband by writing. As she writes, "I had such an Impatiency to see him, having expected him at Dinner, that I was forced to retire to my Closet, to try to divert it, by writing; and the gloomy conclusion of my last, was then the Subject" (Pamela 489).

As a consequence, the heroine of the novel attempts to repress all her unacceptable thoughts and feelings by writing. Indeed, she makes an attempt to displace her sexual instincts and unpleasant thoughts through the act of writing. Eventually she sublimates due to the act of writing, as we can see in the novel after giving birth to her first child, she undertakes an ambitious literary project by her husband's recommendation. As she writes to Lady Davers, "Mr. B. has just put into my Hands Mr. Locke's Treatise on Education, and he commands me to give him my Thoughts upon it in writing" (Pamela 551). Although she undertakes this literary project eventually, at first she is reluctant to accept it due to her fears.

Diane Monique Harris explains that Pamela is frightened to accept Lockean project at first due to her concern that she may appear presumptuous if she agrees "literary coupling with Locke". As she was worried about marriage to B. who was above her social station, now she is concerned about writing above her station (175). As she expresses her concern in a letter to B., "I begin to be afraid I am out of my Sphere, writing to your dear self, on these important Subject" (Pamela 628).

After she has overcome her fears and anxieties, Pamela seriously undertakes this literary project. In second part of the novel, the heroine is fully aware that her letters will be distributed widely among many readers. Thus she is cautious to create "a textual body" which can be circulated among many readers without causing her humiliation and it is the reason that after she has gotten married, she replaces stiff and formal tone with her previous spontaneous and frank tone of her letters (Harris 190). As she explains to B. about her intention to present the world the literary offspring, "as I write with a View only to your Family; tho' you will remember, that while I follow Mr. Locke, whose work is publick, I must be consider'd as if I was directing myself to the Generality of the World" (Pamela 640). Therefore the heroine is unconsciously benefited by displacement as an ego defense mechanism and she displaces all unacceptable thoughts, emotions, and anxieties through writing at the moment which ultimately leads her to sublimation when she cooperates with Mr. Locke in the literary project.

\subsection{The Elements of Uncanny in Pamela}

Freud clarifies that "it is only this factor of involuntary repetition which surrounds what would otherwise be innocent enough with an uncanny atmosphere, and forces upon us the idea of something fateful and inescapable where otherwise 
we should have spoken only of 'chance"' (Freud 942). Furthermore, karey Perkins has stated that the uncanny is at the same time familiar and strange, secure and insecure, known and obscure to our knowledge. Thus, the uncanny is the recurrence of synchronous events with no obvious reason and it is something mysterious and hidden.

\subsubsection{The Idea of Double and Déjà-vu}

Bennet and Royle explain that the uncanny involves strange kinds of repetition, including "repetition of a feeling, situation, event or character; two obvious examples of the uncanny, in this respect, would be the experience of déjà-vu (the sense that something has happened before), and the idea of double (or doppelganger)" (37).

Abrams and Harpham mention that Victorian writers were benefited by using literary double in their writings, for instance, Robert Louis Stevenson in his Dr. Jekyll and Mr. Hyde puts good against evil and also Jane Austin in her Pride and Prejudice places the calm and complaint Jane Bennet against her sister Elizabeth. He continues to say that actually a double or a foil is a character who contrasts with the protagonist and the writer applies it to highlight or emphasize the distinctive temperament of the protagonist (265).

Moreover, Resonfeld clarifies that the novelist who consciously or unconsciously takes advantage of psychological doubles juxtapose two characters recurrently, the one who is a wellspring of the socially acceptable or conventional persona, "the other externalizing the free, uninhibited, often criminal self" (qtd. in Gilbert and Gubar 85).

In Pamela, fallen Sally Godfrey who must now live in disguise as Mrs. Wrighton is a double for the heroine. Actually she is the embodiment of Pamela's repressed instincts and desires of her id which Pamela's ego tries to suppress them and by keeping herself away from Mr. B keenly, at last she is able to climb up the social ladder, and pass through the upper class of society as Squire B's legal wife. Sally Godfrey represents the moral example which has importance in Richardson's novel, since in a society which itself shows a form of psychosis in its oppression of women, the price paid for love is exile and living in disguise up to the end of her life.

Although Pamela becomes successful to be B.'s legal wife and penetrates to upper class, her conduct and apprehensions which she reveals through her letters indicate that she also wishes to become Mr. B's mistress and she secretly desires to violate her parents and their puritan instructions which have shaped her superego. Although Pamela does not fallow her id's destructive desires but Sally does and at last she falls. Thus Sally is sent into exile and also she becomes deprived of her love and child and even her identity since she is forced to continue her life under the name of Mrs. Wrighton.

Margaret Ann Doody, one of Richardson's sympathetic readers, argues that Sally Godfrey section is vital in the narrative of the novel in order to found Pamela in high social class but this section is done in a careless way for its "auspicious" solution of the problem of this part. Like Doody, Mark Kinkead-Weekes suggests the auspicious reading of this section and also a "decisive break with orthodox morality". Kinkead-Weekes clarifies Sally's difficulties are not finished with her failure to resist Mr. B's seduction but she herself took the initiative in her own catastrophe in a great extent. She is only highly influenced by the warning of her childbed terrors which causes her to rush into exile in order to refrain from falling again although she is still in love with her seducer (qtd. in Rivero 54). In a continuation of this discussion, Rivero in his essay states that by victimizing Sally Godfrey, Richardson becomes successful to complete his narrative to save Pamela and also he can display Pamela's goodness, supremacy, forgiveness, and cementation of her love for Mr. B. Thus, any auspicious reading of the case of Sally Godfrey depends on the suppression of her (55).

Pamela is clearly meant to contrast Sally dramatically. For Mr. B, Pamela is everything that is prudent, pure and good, whereas Sally is passionate, tainted and malicious. As Mr. B. himself refers to Sally in this way, "This my Pamela, is the Sally Godfrey this Malicious woman, with the worst intentions, has informed you of" (Pamela 260). Although these two women are contrary in many ways, Sally is Pamela's double. She depicts Pamela's urge to give into passions, to follow her own temptations and to silence the voice of her superego.

Respecting this point, Rivero in his article which was entitled "The Place of Sally Godfrey in Pamela", has explained that Richardson subtly chooses the name of Sally because it connotes breaking of restraints and also going beyond the boundaries of passion and desire. In fact she tends to" fall into little sallies of passion" and also the surname of Godfrey suggests her conflict with the God-head. Moreover, it seems that for Richardson Sally is used to name godless, perverted and fallen women, such as Sally Martin in Clarissa, the prostitute who was faced with horrible fate (59). Indeed, it is after the fall and destruction of Sally that Pamela is able to penetrate to high social class.

Likewise, Polly Barlow Pamela's young and beautiful maid is a sinful double for her. She is seduced by Jacky H. the nephew of Lord Davers and who is a man of quality and she consents to be his mistress. Diane Monique Harris elaborates that the "onomastic similarity" between Pamela and Polly is not coincidental because Polly is Pamela's sinful double, the beautiful maid who was followed and tempted by a man from high social class and she consents to his proposal of being his mistress (205). Pamela herself pays attention to both the similarity and the difference between them when she rebukes Polly for her relationship with Jacky: "But, indeed, Polly, I cannot excuse you. You are under my Protection. I was once in as dangerous a Situation as you can be. And I did not escape it, Child, by the Language and Conduct I heard from you" (Pamela 461).

Harris also clarifies that the parallel between these two characters is prominent by the fact that "Polly's new identity as kept mistress has been consecrated" by text, since Polly makes a confession to Pamela when she tries to discover the depth of their relationship: "I understand you too well But is it too late to break so wretched a Bargain? Have you already made a Sacrifice of your Honour? No, Madam; but I have given it under my Hand" (Pamela 464). Thus, while Pamela refused in her writing to be Squire's B's "kept-mistress contract", her maid admits in her writing to become Mr. 
H.'s mistress (206). As a consequence, Polly gives into passion and temptation which Pamela confronted them and she could overcome with them.

Terry Castle considers the second part of the novel as a kind of "decarnivalization" since it tries to deny the alterable patterns which make the heroine's metamorphosis possible in the first part of the novel. Castle deals with the masquerade episode of Part two and believes that it is a moment of "recarnivalization" due to the flexibility of categories and the union of the opposites. The reader experiences a strange feeling that something is familiar to him, "a kind of déjà-vu, seeing Pamela here, in the midst of universal taxonomic chaos". Additionally, the heroine's body creates an image of festive contradiction because she dresses up as a prim Quaker while she is evidently being pregnant with Mr. B.'s child. Thus, she is the discernible manifestation of carnival confusion. Indeed, the reader remembers her double history and her theatrical violation of distinctions" (130-1).

\subsection{Tripartite Psyche in Pamela}

\subsubsection{Pamela's Hyperactive Superego}

The heroine of the novel was at Lady B.'s service since she was only twelve years old. Thus as an adolescent girl, she faces with her own natural instincts gradually. Likewise, she experiences the situations and circumstances which are unpleasant for her after her Lady's death. Indeed, she is caught between her instinctual desires of the id and the demands of social pressure by her superego. In researchers' view, Pamela suffers from her hyperactive superego, as we can see in many cases throughout the novel which eventually causes her to feel guilty and also she frequently feels ashamed of herself.

Nye discusses that the parents are representative of society indeed. They have several criteria for the right and wrong way of our thoughts, emotions and actions. Other adult members of the society have their own roles in forming these moral criteria. For instance, the social norms and traditions are transferred to children, in most families. Based on Freud's theory, the superego is the embodiment of our parents' values which are blended with one's personage (30).

The heroine's parents have an important role in shaping her superego. With respect to this point, Dussinger states that Pamela's parents have mainly "a choric function" throughout the novel and they interfere in the action very little. From the very beginning of the novel, the Andrews assert the standards of morality, including virtue and honesty for Pamela to act upon and they warn their daughter that she should be cautious about her master's intentions, however, the heroine herself sees no reason to become suspicious of her master's behavior because she is still a child and she cannot recognize that her relationship with her new employer differs from her relationship with her deceased mistress. Thus, she is not able to realize completely her parents' concern over her master's conduct and she becomes puzzled to serve two conflicting forms of authority (379).

Indeed, the Andrews try to convey their puritanical beliefs to their daughter that have considerable influence on her superego. Regarding this point, Watt explains that Puritanism disapproved of romantic love values, but it deems that the relationship of husband and wife has spiritual importance. The idealization of marriage is belonged to Protestantism, in contrast, Roman Catholicism had high regard for celibacy. All sexual activities out of marriage are prohibited severely in Puritanism and it sees man's physical nature "as radically evil, the damnosa hereditas of the Fall". Consequently, virtue itself becomes a matter of suppressing the natural instincts (155-6).

The eighteenth century presents a redefinition of virtue in mainly sexual terms. Dr. Johnson remarked that the man's supreme quality was exhibited in how much he tried to resist his natural impulses which were identified with the passion of love in general. Richardson's attitude was the same as Johnson's since he believed that a good man is always in conflict with his passions throughout his life. Moreover, he clarifies in his novels that these passions are primarily sexual ones (Watt 157).

Watt continues to illustrate that the state of servant girls in eighteenth-century England was observably offensive. The normal fate of domestic servants was distressing since the employers restricted them to stay with them until they married. On the other hand, many employers did not allow them to get married under no circumstances. Due to these economic conditions, the number of unmarried servants in London increased dramatically. The accomplishment of an appropriate marriage for those girls who belonged to middle and low classes of society was very abstruse and it became the main occupation of these girls. Thus, the only chance for the heroine to get rid of the servitude was the marriage to her master which she eventually made (149).

Considering these points, Pamela's insistence on returning to home is referred to those puritan beliefs and the social pressure and codes of the eighteenth-century society which effectively shaped her superego. She is acutely conscious that if she accepts to become his beloved, she will be a social outcast and also she will be rejected by her puritan parents. Furthermore, many critics express their disapproval of Pamela's acceptance of her seducer's marriage proposal. Although in the eighteen century, it was prevailing for servant girls to admit being a paramour of a gentleman, Pamela makes a different decision. Thus, based on the impact of the eighteenth century social codes and also her parents' religious instruction on her superego, she resists the B's temptation. Therefore, she consents to have sexual relationship only in legal form or marriage.

Furthermore, her religious beliefs have a profound impact on her superego and the way she judges on morality. As we can see throughout the novel, she invokes divine providence all the time and all her actions and judgments confirm her beliefs. Thus, divine providence has an active role in Pamela's story line and this is thoroughly palpable in her writing: 
In every State of Life, and in all Changes and Chances of it, for the future, will I trust in Providence, who Knows what is best for us, and frequently turns the very Evils we most dread, to be the Causes of our Happiness, and of our Deliverance from greater! My Experiences, young as I am, as to this great point of Reliance in God, are strong, tho' my Judgment in general may be weak and unformed; but you'll excuse these Reflections, because they are your beloved Daughter's; and, so far as they are not a miss, drive the themselves from the Benefit of yours and my late good Lady's Examples and Instructions (Pamela 166).

Moreover, Pamela's mistress, Mr.B.'s mother, has prominent role in her life. Owing to Lady B., she had a chance of becoming an educated girl. Unlike other girls who belonged to her own class, Pamela had a chance to become an educated girl because of Lady B's favour. Accordingly, when her master attempts to convince her to accept his demand by referring to the story of Lucretia, he tells her "whoever blamed Lucretia, but the Ravisher only?", she responds that "May I, Lucretia like, ... justify myself with my Death, if I am used Barbarously?"(Pamela 23). Notably, through this discussion between them, we realize that Pamela is fully aware of Lucretia's fate. What she has learned from the books, unconsciously affects her superego and the way she judges on morality.

Respecting this point, Wight elucidates that in Roman Legend, Lucretia commits suicide in order to regain her lost virtue and innocence after being sexually violated. Her death causes the banishment of the Tarquins from Rome and foundation of the Roman Republic. The heroine of the novel is aware that if she submits to her master's sexual appeal, she must kill herself to restore her missing purity like Lucretia's action. By killing herself, Lucretia cleans the stigma of rape from her chaste nature, thereby recovering her lost honor. As a result, Pamela menaces Mr. B. to kill herself if she is victimized by his sexual attack (49). Thus, her conscience indicates that the only way to restore her lost virtue due to rape is to kill oneself.

Nye highlights that the superego functions as a kind of internal judgment system which is called conscience. It operates frequently as a strict and uncompromising judge of our thoughts, desires and conduct. It tries to manage the ego by imposing a punishment, for example, conscience arouses the sense of guilt. Superego is an integral part of our character and it can criticize us more intense than our parents and the others. If the superego reaches the highest level of psychic energy which controls our individuality, it can hold the highest amount of dominion over the id and ego. Therefore it arouses a sense of guilt and it prevents the id from fulfilling its natural desires. In addition, the ego's attempts to gain access to real enjoyment, remain unfulfilled (30-1).

As to the primacy of this point, John B. Pierce in his article, "Pamela's Textual Authority" has declared that Pamela continually asks forgiveness "as if she had committed a crime", for instance at the very beginning of the novel, Richardson depicts Pamela in her decedent mistress's dressing-room being interrupted by her master. The significant aspect of this scene is related to the heroine's guilty behavior towards Mr. B since he unexpectedly finds her that she is engaged in writing a letter (30-1). Actually, she has made no mistake about writing a letter, but she behaves in a way that she has made it. She becomes edgy and embarrassed towards her master and begs his forgiveness due to her hyperactive superego. As she describes her feelings in her letter:

I have been scared out of my Senses.; for just now, as I was folding this letter, in my late Lady's dressing-room, in comes my young Master! Good Sirs! How I was frightened! I went to hide the letter in my Bosom, and he seeing me freighted, said smiling, who have you been writing to, Pamela?-I said in my Fright, Pray your Honor, forgive me!-Only to my Father and Mother" (Pamela 11).

Pamela's forgiveness of others who have distressed her like her master and Mrs. Jewkes are stemmed from her hyperactive superego indeed. The heroine's forgiveness proceeds to the point that even she ignored her husband's extramarital affair with the countess, therefore, her reaction indicates that she is paralyzed by her hyperactive superego. In addition, after her marriage, Pamela becomes more submissive and naïve, therefore, the second part of the novel is not as appealing as the first part of it at all and the reader is no longer witness to the heroine's confrontation with her master's demands and she just applauds her master's deeds as a consequence of her hyperactive superego.

Pamela of the early Lincolnshire suffers from paranoia and this temperament stems not only from her captivity by Mrs. Jewkes, the housekeeper, but also from "her regression" while she is frequently looking for her parents' approval. In addition, when she recognizes her own natural instincts and passions, "associated in her mind with the bestiality" which she found in the outer world, eventually causes her revulsion as much as to deny life itself. At first she makes an attempt to manage her chaotic situation by her inquiry to find a way-out and also by her plot to deceive the housekeeper. She becomes more impatient and annoyed since she cannot find her way out of her puzzlement (Dussinger 382). As she writes in her journal: "I have been so used to be made a Fool of by Fortune, that I hardly can tell how to govern myself; and am almost an Infidel as to Mankind" (Pamela 92). Thus she is confused about her feelings since her ego cannot mediate between her recently instinctual desires of the id and the demands of society's moral restrictions, represented by her superego.

Moreover, when the Squire ultimately approves of her departure from Lincolnshire state, Pamela is surprised that she is loath to depart there. Before Pamela arrives at her parents' home, a delivery boy brings her a letter from her master in which he implicitly wishes to marry her and requests her to come back because he is seriously ill. The heroine is exhilarated by receiving this letter. Despite all her efforts to deny her own real feelings and suppress her instinctual 
desires of the id, at this crucial moment she resolves to return to him. Indeed, she surrenders to her id's desire and she goes back to her master in spite of her suspicion to Mr. B's real intention.

In spite of the importance of this climactic moment of the novel, Abjadian clarifies that in an eighteenth century, middle class people had a religious justification for each and every action of themselves. Consequently, Pamela speaks about piety throughout the novel. An intelligent novelist can find middle class's ambitiousness under their religious justification. Notwithstanding all her piety and awareness of her master's sensuality, Pamela is pleased with her marriage to Mr. B., although his moral conversion is not worthy of trust to the readers. The ethical patterns of this novel are, therefore, in conflict with heterogeneous emotions. Mr. B. is an ill-natured and lustful man who cannot resist his unrestrained passion. Pamela is the symbol of purity and she saves her honor through her repeated swoon, but she accepts her master's marriage proposal happily without knowing about his conversion. She forgives her master for making any mistake and she respects and praises him. These facts are in direct contradiction to Richardson's remarks about the decency of virtue and piety and priority of them over social position (458).

According to Dussinger, "Beside the pond, an iconographical image recalling Narssisus' well of despair" she becomes successful in calming herself down. She is grateful for the Devine Grace that makes her change her mind to drown herself in the pond (383). Indeed, she is driven by her death drive for one moment that she decides to put an end to all her difficulties and apprehensions by attempting suicide but suddenly she involuntarily changes her heart owing to her religious belief. She concludes that God would not try her beyond her vigor and even her master may change his mind. Actually her conscience begins to chastise herself as she describes it in the novel:

Then, thought I, who gave thee, presumptuous as thou art, a Power over thy life? Who authoriz'd thee to put an End to it, when the weakness of thy Mind suggests not to thee a way to preserve it with Honour? How knowest thou what Purposes God may have to serve, by the trials with which thou art now tempted? Art thou to put a Bound to God's Will, and to say, Thus much will I bear, and no more? And, wilt thou dare to say, that if the Trial be augmented, and continued, thou wilt sooner die than bear it? (Pamela 107).

Additionally, after Pamela accepted to attend the masquerade reluctantly at her husband's insistence, she became worried about the freedom that was going to pass in this party. She wears a Quaker's dress which Mr. B. has chosen it for her and she feels that this outer habit adapts well to her inner habit due to her puritan beliefs that is effective in shaping her superego. However, when she arrives at the masque she is getting irritated by those who are dressed in Roman Catholic ecclesiastical costumes. Thus the heroine's superego makes a moral judgment by herself, "How else can one account for the Liberties of Expression and Behaviour taken by some of those who personated Bishops, Cardinals, Priests, Nuns, \&c.? For the freeset Things I heard said, were from Persons in those Habits; who behav'd with so much Levity and Indecorum" (Pamela 538).

When the heroine objects to these masqueraders' misbehavior and also their liberties, indeed, as a puritan expresses her sharp disagreement with Roman Catholicism that associates with upper station. Oliver illustrates that those who wear Roman Catholic clerical habits like the nun and cardinal disclose that they are members of the aristocracy through their fluency in foreign languages, their noble carriages and most of all, their immorality, for instance, Mr. B.'s Spanish don attire affiliates with aristocratic corruption and liberties. The heroine asserts her objection to Catholics for two reasons based on social pressure of her time. First, in England Catholics were regarded "as supporters of hereditary rights and hierarchal religious and social systems". Second, since the days of Luther, there were charges of moral laxity against Catholics and many members of low and middle class related moral laxity to the aristocracy (85). Thus her superego makes a judgment based on the social codes and pressures of her class.

\section{Conclusion}

To sum up, it is necessary to acknowledge that Richardson's Pamela dramatized characters who were faced with situations that caused them to experience anxiety, unconscious fears, and also unpleasant feelings since they behaved in a way that was not following their social position as the case of Squire B. or they noticed that their conduct and feelings were in contradiction with their own beliefs and moral codes which were influential in shaping their superego like Pamela's case. Thus, they engaged in their own internal and external conflicts and they made several attempts to apply their ego defense mechanisms unawares to reduce their anxieties.

To this end, Pamela dramatized the depth of the characters' psyche through the heroine's narrative. Pamela's greatly exaggerated kindness and forgiveness referred to the fact that she suffered from her hyperactive superego. Her superego was affected by many crucial factors such as her parents' puritan beliefs, her dear departed lady's instructions and the eighteenth century's social codes and pressures. Consequently, Pamela's superego became hyperactive. For instance, she continually asked her master's forgiveness as if she were guilty. More importantly, she forgave all his faults and misbehavior including his adulterous relationship with the countess.

Furthermore, the elements of the uncanny had an important role in developing the story, such as the castle like settings of novel with the recurrent danger of sexual attack which threatened the heroine's honor. In addition, the roles of double and déjà-vu, the use of surprise like the heroine's fits, the arrival of fortuneteller, and the masquerade scene, all of them were significant elements that would be of use to Freud's theory of the uncanny to Pamela. 


\section{References}

Abrams, M. H., and Harpham, G. (2009). A Glossary of Literary Terms. Boston: Wadsworth Cengage Learning, Print. Abjadian, A. (2012). A Survey of English Literature (II). Tehran: SAMT, Print.

Bennett, A., and Royle, N. (2009). An Introduction to Literature, Criticism and Theory. Harlow (U.K.): Pearson/Longman, Print.

Booker, M. K. (1996). A Practical Introduction to Literary Theory and Criticism. White Plains, NY: Longman, Print.

Castle, T. (1987). Masquerade and Civilization: The Carnivalesque in Eighteenth-century English Culture and Fiction. Stanford, CA: Stanford UP, Print.

Doody, M. A. (1998). Samuel Richardson: Fiction and Knowledge. The Cambridge Companion to the Eighteenth Century Novel. Ed. John Richetti. New York: Cambridge University Press, 90-120. Print.

Dussinger, J. A. (14 Nov 2014). "What Pamela knew: An Interpretation?" English and Germanic philology 69 (1970): 377-93. JSTOR. Web. <www.labs.jstor.org/demo/stable/27705884>.

Eagleton, T. (1983). Literary Theory: An Introduction. Oxford: B. Blackwell, Print.

Fisher, J. W. (1986). Closet-work: The Relationship between Physical and Psychological Spaces in Pamela. Samuel Richardson: Passion and Prudence. Ed. Valerie Grosvenor Myer. London: Vision, 21-35. Print.

Freud, S. (2010). "The Ego and the Id." Freud - Complete Works. Ed. Ivan Smith. 3944-92. PDF.

---. (2010). "The Uncanny." The Norton Anthology of Theory and Criticism. Ed.

Gardner, S. (1991)."The Unconscious." The Cambridge Companion to Freud, Ed. Jerome Neu. Cambridge: Cambridge UP, 136-160. Print.

Gines, Adelaida C. et al. (1998). Developmental Psychology. Manila: Rex Book Store, PDF.

Gilbert, Sandra, and Susan Guber. (20 January 2015). The Mad Woman in the Attic: The Woman Writer and the Nineteenth Century Literary Imagination. Yale UP: New Jersey, 2000. Google Book Search. Web.

Harris, D. M. (1998). Body and Text in Apuleius's The Golden Ass and Richardson's Pamela. Diss. U Torento, 1998. Ottawa: National Library of Canada, PDF.

Hergenhahn, B. R. (1992). An Introduction to the History of psychology. Belmont, CA: Wadsworth Pub., Google Book Search. Web. 22 January 2015.

Keymer, T., and Sabor, P. (2006).'Pamela' in the Marketplace: Literary Controversy and Print Culture in EighteenthCentury Britain and Ireland. Cambridge: Cambridge UP.

Lapsley, D. K., and Stey, P. (2011). Id, Ego, and Superego. Encyclopedia of Human Behavior 1-9. PDF.

Nye, R. D. (2002). Three Psychologies: Perspectives from Freud, Skinner, and Rogers. Trans. Ahmad Jalali. $6^{\text {th }}$ edition. Tehran: Padra. Print.

Shariat Kashani, A. (2015). Psychoanalysis and Literature and Art: From Freud to Jack Derrida. Tehran: Nazar. Print.

Packer, Sh. (2002). Dreams in Myth, Medicine, and Movies. London: Praeger.

Perkins, K. (3 March 2015). The "UNCANNY" as a Defining Feature of Narrative: Coincidence as Both Familiar and Mysterious. 2002. Web. <www.kareyperkins.com/papers/uncanny/html>

Pierce, J. B. (2001). Pamela's Textual Authority. Passion and Virtue: Essays on the Novels of Samuel Richardson. Ed. David Blewett. Toronto UP: Toronto, 8-16. Print.

Richardson, S. (2001). Pamela. Vols 1-4. $1^{\text {st }}$ ed. Blackmask Online, PDF.

Tyson, L. (2006).Critical theory today: a user-friendly Guide. New York: Routledge, Print.

Rivero, A. J. (2001). The place of Sally Godfrey in Richardson's Pamela. Passion and Virtue: Essays on the Novels of Samuel Richardson. Toronto UP: Torento, Ed. David Blewett. 52-72. Print.

Vaillant, G. E. (1992). Ego Mechanisms of Defense: A Guide for Clinicans and Researchers. Washington, DC: American Psychiatric, PDF.

Watt, I. (2001).The Rise of the Novel; Studies in Defoe, Richardson, and Fielding. Berkeley: University of California, Print.

Wight, D. (2012). Still Life: Representations of Passivity in the Gothic Novel. Diss. Albetra U, 2012. Ottawa: Library and Archives Canada, PDF. 